\title{
Desmoglein 3 Antibody Measurement
}

National Cancer Institute

\section{Source}

National Cancer Institute. Desmoglein 3 Antibody Measurement. NCI Thesaurus. Code C122115.

The determination of the amount of desmoglein 3 antibody in a biological specimen. 